\title{
Polishing Methods of an Alumina-Reinforced Feldspar Ceramic
}

\author{
Marco Cícero BOTTINO ${ }^{1}$ \\ Luiz Felipe VALANDRO ${ }^{2}$ \\ Karla Zanini KANTORSKI ${ }^{3}$ \\ José Carlos BRESSIANI ${ }^{4}$ \\ Marco Antonio BOTTINO ${ }^{3}$ \\ ${ }^{1}$ Department of Materials Science and Engineering, University of Alabama at Birmingham, Alabama, USA
2Department of Restorative Dentistry (Prosthodontics), School of Dentistry,
Federal University of Santa Maria, Santa Maria, RS, Brazil
São Paulo State University, São José dos Campos, SP, Brazil
${ }^{3}$ Department of Dental Materials and Prosthodontics, School of Dentistry of São José dompos,
Department of Materials Science and Technology, Institute of Energy and Nuclear Research, São Paulo, SP, Brazil
}

The purpose of this study was to test the hypothesis that mechanical polishing methods of ceramic surfaces allow similar superficial roughness to that of glazed surfaces. Twenty-five Vitadur Alpha ceramic discs $(5 \mathrm{~mm} \times 2 \mathrm{~mm})$ were prepared according to the manufacturer's specifications. All specimens were glazed and randomly assigned to 5 groups $(\mathrm{n}=5)$, according to finishing and polishing protocols: G1: glazed (control); G2: diamond bur finishing; G3: G2 + silicon rubber tip polishing; G4: G3 + felt disc/diamond polishing paste; G5: G3 + felt disc impregnated with fine-particle diamond paste. Next, surface roughness means $(R a-\mu \mathrm{m})$ were calculated. Qualitative analysis was made by scanning electron microscopy. Surface roughness data were submitted to ANOVA and Tukey's test at 5\% significance level. G1 and G4 were statistically similar ( $>>0.05)$. G2 presented the highest roughness means ( $<<0.05)$ followed by groups G3, G5, G4 and G1 in a decreasing order. The hypothesis was partially confirmed as only the mechanical polishing (G4) produced similar superficial roughness to that of surface glazing, although finishing and polishing are technically critical procedures.

Key Words: alumina-reinforced feldspar ceramic, surface roughness, finishing and polishing.

\section{INTRODUCTION}

The increased demand of patients who search for a rehabilitating treatment that esthetically resembles their natural dentition added to the great development of ceramic materials and adhesive techniques have made ceramics one of the most commonly employed materials in Restorative Dentistry.

However, the use of dental ceramics raises some concerns because these materials have to be adequately glazed before placed in the oral cavity $(1,2)$. Non-glazed ceramics have been shown to cause undesirable responses to the adjacent periodontal tissues $(3,4)$, to increase the potential of wearing opposing occlusal surfaces (5) and to be more susceptible to bacterial plaque accumulation (6). In several situations it is necessary to adjust the ceramics in the mouth, even knowing that a new glazing cannot be made anymore. In these cases, the resulting superficial roughness must be minimized with use of intraoral polishing techniques to achieve an acceptable smoothness. This means to make the material as inert as possible (7) in addition to providing good mechanical strength for the restoration (8).

Several methods of finishing and polishing dental ceramics have been proposed to restore the original glaze. However, no currently available method yields an enhanced final glaze (1). The purpose of this study was to evaluate quantitatively (surface roughness analysis)

Correspondence: Mr. Marco Cícero Bottino, 1530 3rd Avenue South, University of Alabama at Birmingham (UAB), Department of Materials Science and Engineering, Birmingham 35294-4461, Alabama, USA. Tel: +1-205-934-6990. Fax: +1-205-934-8485. e-mail: bottino@uab.edu 
and qualitatively (scanning electron microscopy - SEM) the hypothesis that mechanical polishing methods for ceramic surfaces result in similar superficial roughness as that provided by glazing.

\section{MATERIAL AND METHODS}

Twenty-five Vitadur Alpha (VITA Zahnfabrik, Bad Säckingen, Germany; shade 5M3; batch \# 6149R) alumina-reinforced feldspar-based specimens were prepared for this study according to the manufacturer's specifications.

The ceramic material was placed in a metallic matrix with perforations $(5 \mathrm{~mm}$ in diameter and $2 \mathrm{~mm}$ in height) and pressed between two glass plates. Thereafter, the material was sintered following the recommended temperature cycle in a Vacumat furnace (VITA Zahnfabrik, Bad Säckingen, Germany).

Excess material was removed using \#718 diamond bur (KG Sorensen, Barueri, SP, Brazil) at low speed and the specimens were finished using a series of siliconcarbide abrasive papers (grits 600, 800, 1000, 1200; Buehler, Lake Bluff, IL, USA), and ultrasonicated (Vitasonic; VITA Zahnfabrik) in distilled water for 5 min. The bottom surfaces of all specimens were submitted to two subsequent glazing procedures using Akzent 24 (VITA Zahnfabrik; batch\# liquid: 6424A, batch\# powder: $6127 \mathrm{~S}$ ), following the temperature cycle recommended by the manufacturer.

The specimens were randomly assigned to 5 groups $(\mathrm{n}=5)$. In each group, finishing and polishing were performed with specific materials and according to the techniques recommended by their respective manufacturers: G1: no finishing was done and the glazed surfaces remained intact (control); G2: finishing with \#4138 diamond bur (KG Sorensen; batch\# 020605); G3: finishing with \#4138 diamond bur and polishing with silicon rubber tips (KG Sorensen; batch \# 9232PM); G4: finishing with \#4138 diamond bur, polishing with silicon rubber tips and felt disc with $6-\mu \mathrm{m}$ diamond paste (KG Sorensen; batch \#7023); G5: finishing with \#4138 diamond bur, polishing with silicon rubber tips and felt disc impregnated with a fine-aluminum oxide particle based paste $(5 \mu \mathrm{m})$ (TDV, Pomerode, SC, Brazil). Each step was done for 10 s. Finally, all specimens were ultrasonicated and submitted to surface roughness analysis.

Surface roughness was analyzed in a roughness tester (Mitutoyo SJ-201P Mfg. Co. Ltd., Tokyo, Japan). Six measurements were performed for each specimen, following the $R a(\mu \mathrm{m})$ parameter: 3 parallel measurements and 3 perpendicular measurements were made at a distance of $1 \mathrm{~mm}$ to each other. A mean value was obtained from these 6 measurements. The $R a$ value provided a mean surface roughness value for each specimen, that is, the mean profile height above (peak) and below (hill) the central line.

Surface roughness data were analyzed statistically by ANOVA and Tukey's test at 5\% significance level.

In addition to the quantitative analysis, one specimen per group was examined under scanning electron microscopy using a JEOL-JSM-T330A microscope (Jeol Ltd, Tokyo, Japan). The topographic observations of the surface treatments were compared to each other as a complement for the quantitative results obtained with surface roughnes assessment.

\section{RESULTS}

\section{Quantitative Analysis - Surface Roughness}

The surface roughness means $(R a-\mu \mathrm{m})$ ( \pm standard deviations) recorded in the 5 groups were as follows: $\mathrm{G} 1=0.94 \mathrm{a} \pm 0.2 ; \mathrm{G} 2=3.01 \mathrm{~b} \pm 0.1 ; \mathrm{G} 3=2.02 \mathrm{c}$ $\pm 0.07 ; \mathrm{G} 4=1.24 \mathrm{ad} \pm 0.10 ; \mathrm{G} 5=1.77 \mathrm{~cd} \pm 0.68$. Means followed by different letters indicate statistically significant difference at 5\%.

G1 (control) presented the lowest surface roughness means but did not differ significantly from G4 (p>0.05). G4 and G5 were statistically similar to each other $(p>0.05)$. G2 showed the highest surface roughness means $(p<0.05)$ whereas G3 had an intermediate result compared to other groups.

\section{Qualitative Analysis - SEM}

Figures 1 to 5 show SEM micrographs of the ceramic surface in each group. G1 (Fig. 1) presented the smoothest topographic pattern when compared to the other groups (Figs. 2-5). Comparing Figures 2 and 4 , it is possible to notice that the polishing procedures minimized the surface irregularities.

Likewise, for G3 (Fig. 3), the surface irregularities and voids were reduced by polishing with rubber tips, even though some voids still persisted. 


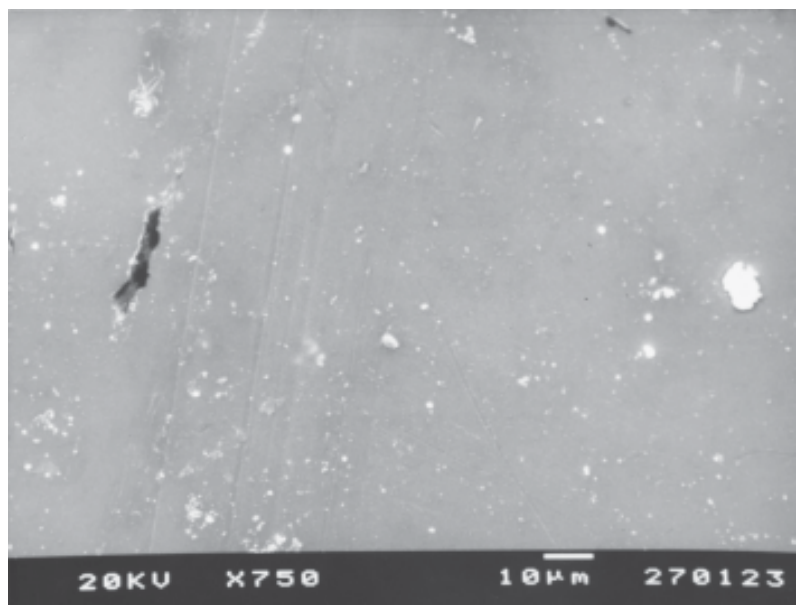

Figure 1. SEM micrograph of Group 1 (glazed - control).

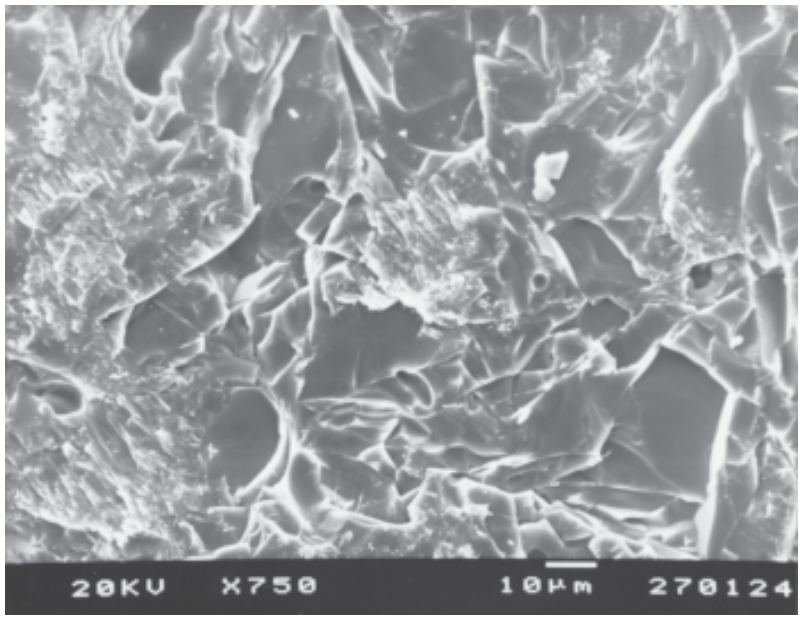

Figure 2. SEM micrograph of Group 2 (diamond bur finishing).

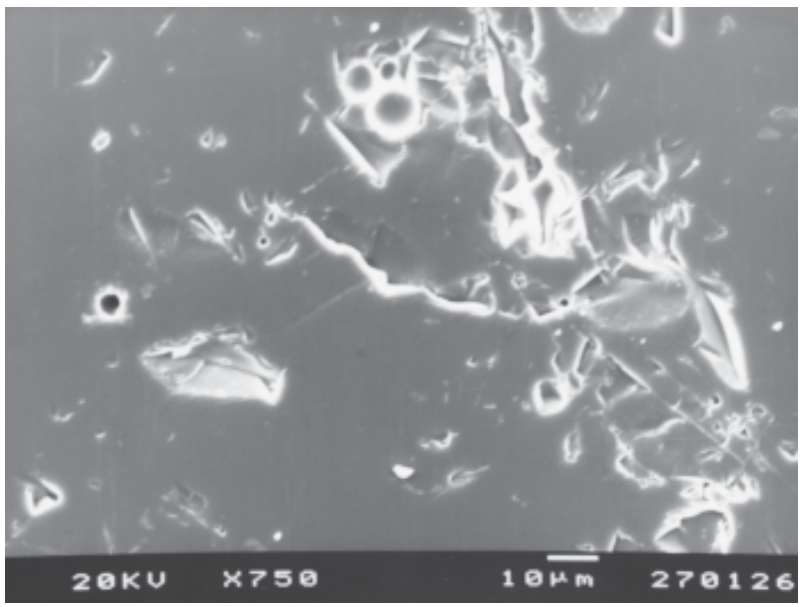

Figure 4. SEM micrograph of Group 4 (diamond bur finishing + silicon rubber tip polishing + felt disc/diamond polishing paste).

\section{DISCUSSION}

Based on the findings of the present study, it may be stated that mechanical polishing was not able to reestablish an adequate surface polishing in comparison to the original glazed surfaces. SEM may be used to complement the quantitative analysis yielded surface roughness assessment.

Several studies have evaluated finishing and polishing techniques for ceramic materials because occlusal adjustments are often required after cementation and much has been discussed regarding the negative impact of rough ceramic surfaces.

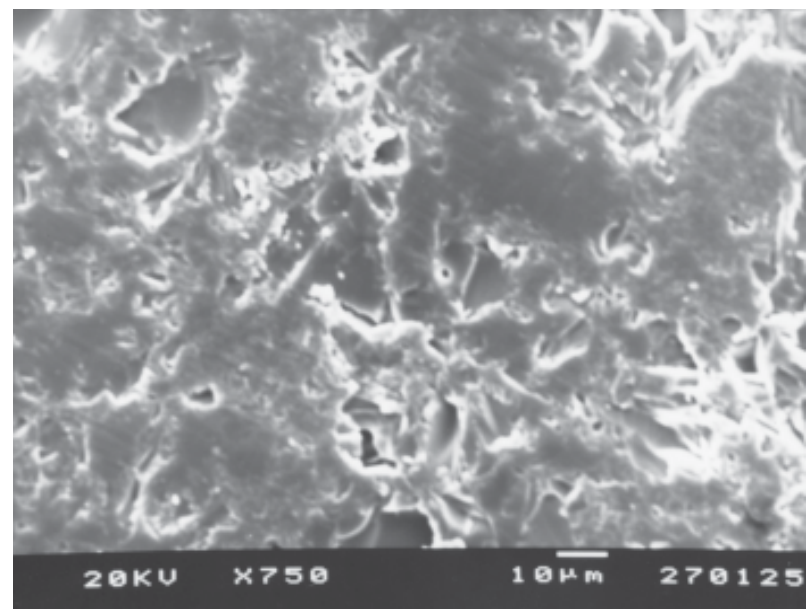

Figure 3. SEM micrograph of Group 3 (diamond bur finishing + silicon rubber tip polishing).

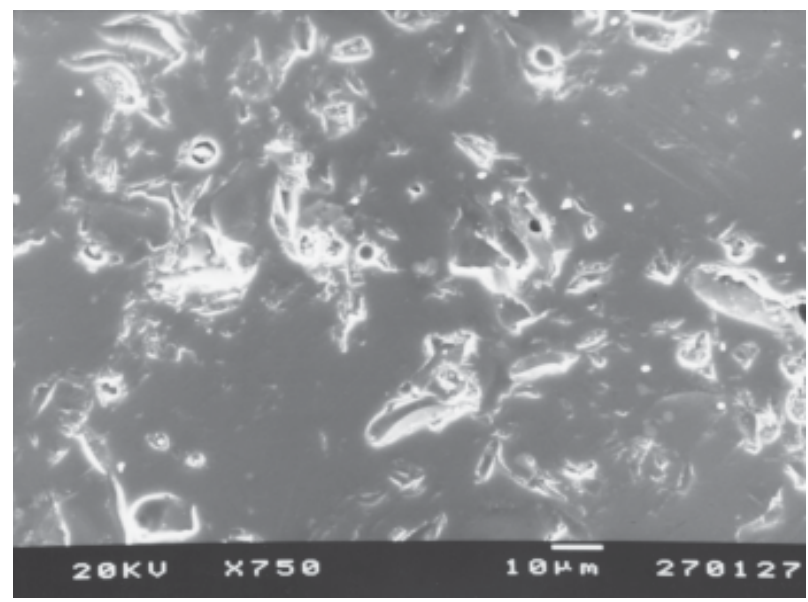

Figure 5. SEM micrograph of Group 5 (diamond bur finishing + silicon rubber tip polishing + felt disc impregnated with fineparticle diamond paste). 
Finishing of a restoration starts with preliminary polishing of rough surfaces (9). Final polishing with extremely fine abrasive materials reduces roughness. Polishing of the external surface of restoration is important because rough surfaces facilitates bacterial plaque accumulation (10) and may lead to wearing of opposite teeth (11). Moreover, effective polishing prevents discoloration of rough areas and leads to a more natural appearance of ceramic restorations. Rough or irregular ceramic surfaces after intraoral adjustment may concentrate stresses and initiate cracking propagation resulting in premature fracture of the restoration (12).

The findings of the present study showed that the smoothest ceramic surfaces were obtained after glazing. After finishing with diamond burs (simulating occlusal adjustments), the use of abrasive rubber tips and felt discs with diamond paste reestablished acceptable surface roughness. However, although the surface roughness means obtained for these 2 groups (G1 and G4) were similar to each other, the analysis of Figures 1 (G1) and 4 (G4) shows that their topographic patterns has some differences. Figure 1 shows a smooth surface with superficial irregularities, whereas Figure 4 shows that internal failures caused by diamond bur finishing still remained after the subsequent polishing. Therefore, although no statistically significant difference was found between these surface treatments, the topographic analysis revealed that the diamond bur-finished ceramic surfaces remained with irregularities, even when the polishing procedures were carried out as proposed in G4 (abrasive rubber tips + felt disc with diamond paste).

Therefore, it is advisable that quantitative analysis by surface roughness is accompanied by qualitative analysis by SEM because even when finishing/polishing procedures are deemed to have similar performance based on surface roughness analysis, their topographic patterns can be different. In view of this, other authors (13) have suggested that in addition to using the common $R a$ parameter, other roughness parameters such as $\mathrm{Rz}$, $\mathrm{Rpm}, \mathrm{Pc}$ and $\mathrm{Rpm} / \mathrm{Rz}$ should also employed to analyze surface roughness of ceramic materials.

G4 presented significantly lower surface roughness than G2, regarding topographic features (Figs. 2 and 4). This indicates that when a highly roughened surface resulting from adjustment with diamond burs was polished it was possible to achieve a smoother surface, either according to numerical or topographic analysis, although voids remained after the sequence proposed for $\mathrm{G} 4$.

Comparing $\mathrm{G} 2$ and $\mathrm{G} 3$, a significant reduction on roughness means was noticed $(3.01 \mu \mathrm{m}$ to $2.02 \mu \mathrm{m})$. The topographic pattern observed for G2 (Fig. 2) showed an extensively rough surface. For G3 (Fig. 3), irregularities and voids were reduced by finishing with rubber tips, although some voids still remained. Figure 4 illustrates another step of the polishing procedure, now using felt disc and diamond paste, and a reduction on surface irregularities can be observed, confirming the lowest values obtained for G4.

Based on the results obtained in this study, it may be suggested that clinical polishing of roughened ceramic surfaces due to occlusal adjustment with diamond burs should be performed using abrasive rubber tips followed by felt disc with diamond paste. The use of abrasive rubber tips is of ultmost importance to achieve a more adequate surface to final polishing with felt disc and diamond paste. Diamond polishing pastes must present fine particle size to allow surface polishing, but not so fine to be ineffective when used for ceramic restorations.

The outcomes of the present study also revealed that the particle size and the use of great amount of paste during polishing procedures are fundamental to provide smoothest surfaces, as observed by comparing G4 and G5. Both used the same finishing and polishing sequence, but in G4, the paste was applied directly to the ceramic surface and then a felt disc was used, whereas in G5 the felt disc was impregnated with paste.

Within the limitations of this study, the following conclusions my be drawn: a) the tested hypothesis was partially accepted because only one polishing method (G4) allowed similar superficial roughness to glazing (G1); b) the other polishing methods (G2, G3 and G5) produced higher superficial roughness than glazing alone (G1); c) clinically, adjusted ceramics should always be polished to produce a smoother surface.

\section{RESUMO}

O objetivo deste estudo foi testar a hipótese de que o acabamento e o polimento da superfície cerâmica produzem rugosidade superficial semelhante à superfície cerâmica vitrificada. Vinte e cinco corpos-de-prova ( $5 \mathrm{~mm}$ x $2 \mathrm{~mm}$ ) da cerâmica Vitadur Alpha foram obtidos de acordo com as recomendações do fabricante. Todas os corpos-de-prova foram vitrificados e aleatoriamente divididos em 5 grupos $(n=5)$, de acordo com os seguintes protocolos de acabamento e polimento: G1: vitrificação (controle); G2: abrasão com ponta diamantada; G3: G2 + acabamento com borrachas abrasivas; G4: G3 + polimento com pasta diamantada/ 
disco de feltro; G5: G3 + disco de feltro impregnado com pasta diamantada. Após 6 análises individuais foi obtida 1 média por corpo-de-prova da rugosidade $(R a)$. A análise qualitativa foi realizada por microscopia eletrônica de varredura. Os valores médios de rugosidade foram submetidos à ANOVA e ao teste de Tukey com nível de significância de 5\%. G1 e G4 foram estatisticamente semelhantes $(\mathrm{p}>0.05)$. O grupo $\mathrm{G} 2$ apresentou o maior valor médio de rugosidade $(\mathrm{p}<0.05)$ seguido por $\mathrm{G} 3, \mathrm{G} 5$, G4 e G1 em ordem decrescente. A hipótese foi parcialmente confirmada, pois somente o polimento mecânico do grupo G4 produziu rugosidade superficial semelhante à da superfície vitrificada, embora o acabamento e o polimento sejam procedimentos críticos tecnicamente.

\section{ACKNOWLEDGEMENTS}

The authors would like to thank Dr. Ivan Balducci (UNESPFOSJC) for the statistical analysis, to Dr. Eliane Placido for her assistance in English review and to Wilcos (Brazil), KG Sorensen (Brazil) and Vita Zahnfabrik (Germany) for supplying the materials used in this study.

\section{REFERENCES}

1. Barghi N, Lee A, Draughn RA. When to glaze - An electron microscope study. J Prosthet Dent 1976;35:648-653.

2. Goldstein GR, Barnhard BR, Penugonda BJ. Profilometer, SEM, and visual assessment of porcelain polishing methods. J Prosthet Dent 1991;65:627-634.

3. Stein RS. Pontic residual ridge relationship: a research report. J Prosthet Dent 1966;16:251-285.

4. Caputo AA. Biological implications of dental materials. Dent Clin North Am 1980;24:331-341.
5. Monasky GE, Taylor DF. Studies on the wear of porcelain, enamel and gold. J Prosthet Dent 1971;25:299-306.

6. Swartz ML, Phillips RW. Comparison of bacterial accumulation on rough and smooth enamel surfaces. J Periodontol 1957;28:304-307.

7. Patterson CJW, McLundie AC, Stirrups DR, Taylor WG. Efficacy of a porcelain refinishing system in restoring surface finish after grinding with fine and extra-fine diamond burs. J Prosthet Dent 1992;68:402-406.

8. Jager N, Feilzer AJ, Davidson CL. The influence of surface roughness on porcelain strength. Dent Mater 2000;16:381388.

9. Jung M. Finishing and polishing of a hybrid composite and a heat-pressed glass ceramic. Oper Dent 2002;27:175-183.

10. Rimondini L, Farè S, Brambilla E, Felloni A, Consonni C, Brossa F, Carrassi A. The effect of surface roughness on early in vivo plaque colonization on titanium. J Periodontol 1997;68:556-562.

11. Jagger DC, Harrison A. An in vitro investigation into the wear effects of unglazed, glazed, and polished porcelain on human enamel. J Prosthet Dent 1994;72:320-323.

12. Fisher H, Schafer M, Marx R. Effect of surface roughness on flexural strength of veneer ceramics. J Dent Res 2003;82:972975.

13. Agra CM, Vieira GF. Quantitative analysis of dental porcelain surfaces following different treatments: Correlation between parameters obtained by surface profiling instruments. Dent Mater J 2002;21:44-52.

14. Haywood VB, Heymann HO, Scurria MS. Effects of water, speed, and experimental instrumentation on finishing and polishing porcelain intra-orally. Dent Mater 1989;5:185188.

Accepted June 24, 2004 